\title{
Vic Suneson - Från svensk noir till polisroman
}

\section{Ulf Carlsson}

Av 50-talets ledande svenska kriminalförfattare var Vic Suneson den som representerade genrens förnyelse. Suneson förebådade den polisroman som fick sitt genombrott i Sverige under nästa decennium. Han visade i flera romaner en stark inspiration från den samtida filmens teknik och tematik, i synnerhet från amerikansk s.k. film noir. En av hans deckare, Är jag mördaren?, överraskade med metafiktiva grepp som ställde genrens krav på illusionsverkan i ironisk belysning. Men samtidigt förblev Suneson i andra avseenden trogen den klassiska detektivberättelsens mönster, hans produktion kom att präglas av kompromiss mellan gammalt och nytt. Där fanns fortfarande den traditionella inriktningen på en gåta med ett begränsat antal misstänkta och en överraskande upplösning. Dessutom - efter att i några romaner ha lanserat en huvudperson, avsevärt labilare än vad genrenormerna medgav - stannade till sist även Suneson för en mera välanpassad polishjälte. Kommissarie O. P. Nilsson gav den trygghet och ideologiska bekräftelse man ofta uppfattat som kännetecknande för genren.

Sunesons debutverk, Mord kring Maud, 1948, innehåller ett inslag som redan då annonserar författarens förtjusning i motiv typiska för såväl film noir som för den dåtida romanthrillern, i det här fallet den mordmisstänkte som drabbats av minnesförlust. ${ }^{1}$ Fortsättningsvis kommer jag dock att uppehålla mig vid sex andra romaner: I dimma dold, 1951, ̈̈r jag mördaren? och Fäll inga tårar, båda från 1953, Döden kastar långa skuggor, 1954, Och häcken växte, 1955, samt Så spelar döden, 1956. I förbigående berörs även några av Sunesons senare böcker.

Fäll inga tårar, är Sunesons djärvaste försök att vidga genregränserna. Han använder sig här av en komplicerad litterär teknik, betydligt mer svårtillgänglig än hos någon av rivalerna Stieg Trenter och Maria Lang. Det är också den av hans romaner som tagit starkast intryck av film noir, både vad gäller berättargrepp och motiv. Texten är alltså intressant både därför att den avviker från den dåtida kriminalromanen och därför att den är så tydligt inspirerad av filmen. I två avsnitt kommer artikeln att diskutera Fäll inga tårar framförallt från dessa aspekter, men också hur Suneson utformar sin polisroman i jämförelse med andra samtida texter om polisen, både inom litteratur och film. Avslutningsvis berör jag vilka ideologiska mönster som kan utläsas ur Sunesons 50-talsromaner.

\section{Fäll inga tårar - svensk noir}

Beteckningen noir har använts även om skönlitteratur, tidigast i den franska kriminalromanserien Série Noire, som började publiceras vid slutet av andra världskriget. Termen har sedan

1 Motivet återfinns bl.a. i Cornell Woolrichs The Black Angel, filmad av Roy William Neill under samma titel 1946 (Objuden gäst), och i Joseph Mankiewicz' film Somewhere in the Night (Jagad i natten), också från 1946. 
återkommit i t.ex. Paul Duncans populärt hållna Noir Fiction, Dark Highways (2000) och i Lee Horsleys mera omfattande och akademiskt präglade studie The Noir Thriller (2001). Såväl Duncan som Horsley fokuserar på en krets av amerikanska kriminalförfattare från 30-talet och efterkrigstiden - främst James M. Cain, Cornell Woolrich, Jim Thompson och David Goodis. De betonar också den betydelse den hårdkokta kriminalromanens främsta företrädare - Dashiell Hammett och Raymond Chandler - haft för utvecklingen av den mörka syn på tillvaron som förenar samtliga dessa namn och framhäver till sist även släktskapen med Feodor Dostojevskij, Joseph Conrad, Albert Camus och Graham Greene. ${ }^{2}$

Samtliga de ovannämnda amerikanerna har, liksom Greene, via sina romaner gett underlag till filmatiseringar som i sin tur uppfattats som stilenlig film noir. Filmens beroende av litteraturen har också genomgående betonats i översiktsverken inom området. För Vic Suneson förefaller det emellertid tydligt att hans romaner snarast måste ses som ett exempel på trafik i motsatt riktning. Möjligen kan man dessutom anta att Cornell Woolrich fungerat som ett mönster för en litterär teknik som tydligt tillvaratar olika grepp hämtade från filmen, bl.a. i den till svenska översatta The Night has a Thousand Eyes, 1945 (Natten har tusen ögon, 1947). Den högdramatiska finalen i Fäll inga tårar överensstämmer också på ett slående vis med avslutningen i Woolrichs roman. ${ }^{3}$

Det filmintresse som framträder i Fäll inga tårar hade varit uttalat redan i Sunesons båda närmast föregående romaner. I dimma dold från 1951 refererar återkommande och öppet till Otto Premingers Laura från 1944, en filmatisering av en kriminalroman med samma titel av Vera Caspary. Laura tillhörde för övrigt den lilla grupp på fem amerikanska filmer som några franska kritiker pekade ut då de vid krigsslutet lanserade termen film noir. ${ }^{4}$ Huvudpersonen hos Suneson heter "Lora"; liksom i Premingers film fascineras den polisman som handhar fallet, här Kjell Myrman, av kvinnans porträtt; och både han och flera andra påminns under handlingens gång om filmen och den melodi som samtidigt blev känd. Romanen berättas dessutom med täta återblickar som erinrar om filmens flashback-teknik. Sunesons nästa roman, Är jag mördaren?, 1953, börjar med en mordgåta inom filmproduktionens värld och där jag-berättaren ofta beskriver skeendet med hänvisning till filmiska intrigmönster. Suneson var under detta år var också upptagen med att skriva manus till filmatiseringen av $I$ dimma dold och samtidigt inkopplad på ett annat filmprojekt, för övrigt parallellt med Stig Dagerman. ${ }^{5}$

2 Horsleys främsta kännetecken på "noir thrillers" överensstämmer väl med vad som i andra sammanhang har fătt beskriva film noir: "i) the subjective point of view; ii) the shifting roles of the protagonist; iii) the ill-fated relationship between the protagonist and society (...); iv) the ways in which noir functions as a socio-political critique". Lee Horsley, The Noir Thriller, Palgrave 2001, s. 8.

3 Om Woolrichs filminspirerade teknik, se Frank Krutnik, In a Lonely Street: Film Noir, Genre, Masculinity, Routledge 1994, s. 41. Woolrichs roman avslutas liksom Fäll inga tårar med att en av huvudpersonerna kastar sig genom en glasruta och får halsen avskuren. Cornell Woolrich (George Hopley), Natten har tusen ögon (The Night has a Thousand Eyes, 1945), Askild \& Kärnekull 1973.

4 James Naremore, More than Night: Film Noir in its Contexts, University of California Press 1998, s. $11 \mathrm{ff}$.

5 Gösta Werner, De grymma skuggorna. En studie i Stig Dagermans författarskap och dess relationer till filmen som medium, Norstedts 1986, s. 150 f. 
Fäll inga tårar låter oss redan i inledningen möta "mördaren" i hans ensamhet på ett sjaskigt hyresrum. Några sidor senare namnges han som Stefan Marck, varefter hans livshistoria presenteras via en biografisk skiss tillbaka till hans barndom. Det framgår att Marck är författare av radiopjäser och filmmanuskript, att han har bakom sig ett upplöst äktenskap med Carina Strand, och att han därefter haft ett förhållande med veckotidningsillustratören Vivianne. Genom en serie återblickar får läsaren följa hur Vivianne hånskrattande avslutar deras relation samma dag som skilsmässan från Carina är klar, hur Stefan Marck ger henne ett knytnävsslag som leder till hennes död då hon faller i badkaret, och hur han sedan beger sig på flykt inom Stockholm. Berättelsen om den desperate och skuldtyngde Marcks fortsatta öden ges parallellt med den om polisens utredningsarbete. Carina Strand är länge den huvudmisstänkta, men kriminalkommissarien Kjell Myrman och överkonstapel O. P. Nilsson upptäcker också att Vivianne varit narkoman och uppenbart knuten till en langarkrets, vars okända huvudman går under beteckningen Doktor Sömn. I den spektakulära slutfasen blir en av narkotikaligans underhuggare, Scizo, bränd till döds av en elkabel, sittande i en grävskopa i den jättelika grop som uppstått vid tunnelbanebygget i City. Myrman finner Marck, som kastar sig ut genom ett fönster och får halsen avskuren på ett sätt som tydligt erinrar om en giljotinering. Ännu på sista sidan är sammanhangen i historien oklara för Myrman och Nilsson. Läsaren däremot vet att Marck fallit offer för den plan som Vivianne ursprungligen gjort upp med sin make i ett hemligt giftermål, Alf Aramo, vilken också är identisk med den mystiske Doktor Sömn. Aramo är kusin med Carina Strand och har med hjälp av Vivianne velat åstadkomma en definitiv söndring i hennes äktenskap med Marck, detta för att garantera sitt eget barn ett förväntat storarv från en gemensam släkting i USA.

Fäll inga tårar framstår som präglad av den efterkrigssituation, då olika alternativ till pusseldeckaren började ta form. Suneson kan på en gång sägas anknyta till den framväxande polisromanen, till den thriller av Cornell Woolrichs snitt som gärna satsade på ytterst effektfulla inslag, och till den psykologiskt inriktade kriminalroman som 1950 fått ett mönsterbildande exempel översatt till svenska med Georges Simenons Mannen som såg tågen gå förbi (L'Homme qui regardait passer les trains). Också Simenon skildrar, om än med andra förtecken, en borgerlig existens som genom att begå ett brott faller ut i samhällets marginal och blir jagad av polisen.

Sunesons roman kretsar i hög grad kring relationen mellan Myrman och Marck, jägaren och den jagade, två karaktärer som möts först i slutfasen men som efterhand visar sig bära på flera likheter. Samtidigt torde redan en kort summering av händelseförloppet avslöja de svårigheter Suneson haft med intrigen. Ambitionen att ge ett realistiskt och psykologiskt inträngande porträtt av den olycklige Marck harmonierar illa med den långsökta konspirationshistoria som till sist avslöjas.

Romanens brokighet ifråga om syften och handlingstrådar avspeglades i de dåtida recensionerna. Mottagandet av Fäll inga tårar blev minst sagt blandat. Medan signaturen Pillerthrillaren i StockholmsTidningen talade om "den kanske bästa deckare som skrivits på svenska" och berömde både historiens trovärdighet och en "överlägset säker" människoskildring, ${ }^{6}$

6 Pillerthrillaren, ”Thriller-piller”, StockholmsTidningen 5.11.1953. 
menade Bang i Dagens Nyheter att "slutet är bland det mest otillfredsställande som förekommit i svensk kriminallitteratur" och vände sig mot Sunesons sätt att "mixa ren kriminalteknik med syften som är helt andra än att lösa en mordgåta". ${ }^{7}$ Steinar Olsen i Aftontidningen framhöll i en alltigenom berömmande anmälan Sunesons "övertygande porträtt av de intellektuella typer han förälskat sig i" ${ }^{8}$ Hans Ullberg i Expressen irriterade sig däremot liksom flera andra på en "förbryllande" komposition som gjort "hackmat av berättelsen, styckat upp den i en mängd mindre avsnitt". ${ }^{9}$ Romanen har uppenbart inbjudit till olika läsarter, men framförallt är kritikerkåren långt ifrån enhälligt fördömande mot Sunesons försök att bryta mot de pusseldeckarens mönster, som annars dominerande inom 50-talets svenska kriminallitteratur.

Fäll inga tårar är uppdelad i 14 kapitel och sammanlagt 72, ofta förhållandevis korta avsnitt, skilda från varandra genom blankrad eller kapitelslut. 25 av dessa avsnitt har Stefan Marck i centrum, lika många har Kjell Myrman, medan resten fördelas på tio andra karaktärer eller på scener som saknar något egentligt centrum. Avsnitten kring Marck och Myrman präglas nästan genomgående av intern fokalisering, d.v.s. skeendet upplevs via dessa karaktärers medvetande. I vissa passager framträder däremot en auktoritativ och tydligt värderande berättarröst, så t.ex. i den tidiga biografiska skissen. Särskilt i romanens början, då Marck tänker tillbaka på de händelser som lett fram till Viviannes död, har avsnitten en kronologiskt komplicerad relation till varandra. I andra fall kan de tilldra sig parallellt. Början och slut anknyter till varandra. Den ödesdigra knackning på dörren till Marcks hyresrum som avslutar första avsnittet återkommer i det nästa sista och då med formuleringar som är nära nog ordagrant desamma.

Med det är inte bara de täta växlingarna mellan scen och fokalisator som kännetecknar Fäll inga tårar. I något fall tydliggör inte Suneson hur ett avsnitt relaterar till det större sammanhanget, utan överlåter detta på läsaren (s. 155 f). Vid flera tillfällen maskeras dessutom bytet av fokalisator så att läsaren först efterhand kan utläsa vilket medvetande som står i centrum. Tekniken återkommer relativt ofta och tjänar bl.a. till att understryka likheterna mellan de båda huvudpersonerna, Marck och Myrman, som båda plågas av alkoholproblem och ett trasigt själsliv. Ett avsnitt med Marck i centrum slutar:

Genom fönstret såg han ut över Strömmen och stadens tusens ljus. Allt var tyst och mörkt. Det blev en liten pöl kring hans fötter. Omedvetet flyttade han sig från mattan i hallen och ut på parketten i vardagsrummet. Så gick han tillbaka och släckte i hallen. Och så in i vardagsrummet, där han sjönk ner i soffan med ryggen mot väggen, tryckt upp mot hörnet, lyssnande efter steg som inte fanns och till röster som inte hördes.

Stirrande ut i natten.

I trygghet? (s. 51)

Efter blankrad fortsätter det:

7 Bang, "Tår på tand”, Dagens Nyheter 10.11.1953.

8 Steinar Olsen, "Vic Suneson i toppform", Aftontidningen 2.11.1953.

9 Hans Ullberg, "Pytt i panna”, Expressen 5.11.1953. 
En bil svepte förbi utanför på gatan. Den måste ha kört med starka lyktor eftersom det glimmade till i fönsterpostens vita fält. Kanske var det den av regnet blanka asfalten som hjälpte till. Kanske var han allmänt känslig för ljusglimtar.

Han som just nu gick i ett stort och ogripbart mörker och letade efter ledtrådar.

Förbannade historia.

När gäddorna lekte i vassarna och skärgården låg trygg och fin utanför åskvädrens räckvidd, när sensommarvärmen ångade över heta klippor och man borde ligga med segelbåten och kryssa mellan vindspolade grynnor i havsbandet, när man borde ha det lugnt och skönt. (s. $51 \mathrm{f}$ )

Först efter ett antal rader ges antydningar om att fokalisatorn nu är Myrman, något som senare bekräftas till fullo. Övergången de två avsnitten emellan blir också ett av flera exempel på hur texten utnyttjar en motsvarighet till det som inom filmen kallas "graphic match", d.v.s. att två tagningar fogas samman på grund av bildmässig likhet.

Fäll ing a tårar uppvisar generellt en större narrativ variation och mer avancerade berättargrepp än någon annan av Sunesons romaner. Både i sina tidigare och sina efterföljande texter föredrar han det konventionella tankereferatet eller registrerar i vissa scener enbart repliker, minspel och handling utan att ge inblick i något medvetande. Här använder han däremot gärna erlebte rede, inre monolog eller en hybridform av dessa båda vägar att ge läsaren inblick i en karaktärs medvetande. Den senare delen av citatet ovan ger exempel och kan kompletteras med ett försök till mera renodlad inre monolog, i det här fallet ett stycke som återger tankeströmmen hos den förvirrade Marck som börjar vakna till liv ute i regnet en stund efter dråpet på Vivianne:

När jag vänder mig gör det ont. Någonstans i ryggen. Alltså vänder jag inte på mej. Det är som en...nej, inte en kniv. Det är som dånet från ett vattenfall som går rätt genom min rygg.

Och så regnet. Regnet som är mjukt och skönt och nästan varmt mot mitt ansikte, men som är så... ofrånkomligt, som tårar i månljus, som något jag vill men ändå inte vill. Något jag önskat komma ifrån men ändå inte vill komma ifrån. Något inom mej som jag inte har velat och ändå måste ha velat. Något jag aldrig vågat tänka men ändå tänkt. Regnet är ...försonande.

Försonande?

Badkar?

Jag måste nog vända litet på mej, ändå. Knivarna får väl...vridas om i...aaah. (s. 45)

Gärna förstärker Suneson Stefan Marcks grubbel med en upprepningsteknik som kan bli överdrivet monoton. Flera avsnitt i romanen domineras av Marcks dystra tankar sidor i sträck och innehåller föga av den yttre spänning kriminalromanen oftast syftat till (s. 44-51, 122129, 189-195). Suneson närmar sig tekniker som blivit vanliga i den modernistiskt färgade 40-talsprosan, hos diktare som Dagerman, Arnér och Thorsten Jonsson. Viktigt i sammanhanget är att Stefan Marck har åtskilligt gemensamt med de ångestpinade figurer man kan finna hos framförallt Dagerman, f.ö. ännu en författare med kärlek till film noir. ${ }^{10}$

10 Dagermans relation till film noir i romanen Bränt barn har analyserats i Anders Ohlsson, Läst genom kameralinsen. Studier i filmiserad svensk roman, Nya Doxa 1998. Jag är tacksam för flera idéer från Ohlssons bok. 
Sunesons roman präglas av den inspiration han funnit i den samtida amerikanska kriminalfilm, som redan vid krigsslutet började betecknas som film noir i Frankrike. Också den första boken i ämnet skrevs av två fransmän, Raymond Borde och Etienne Chaumeton, 1955, medan det märkligt nog dröjde ända till 70-talet innan termen kom till vidare användning i USA. Paul Schrader publicerade då en betydelsefull artikel, som sedan har följts av dussintals volymer kring film noir. Teoretikerna på området har presenterat ett antal olika definitioner, där film noir omväxlande har uppfattats som en "serie", en "cykel", en "genre", en "stil", eller som i några sentida verk, en kombination av flera av dessa innebörder eller t.o.m. en "diskurs". ${ }^{11}$ Oenigheten har vanligtvis förklarats som en effekt av att termen ursprungligen användes på ett ganska subjektivt sätt, snarast för att beskriva ett nytt och mörkare stämningsläge i den amerikanska filmen, och att ett stort antal, sinsemellan ibland olikartade filmer, sedan har adderats till den ursprungliga gruppen - Film Noir: An Encyclopedic Reference to the American Style från 1988 förtecknar inte mindre än 317 filmer. ${ }^{12}$ Faktum kvarstår, att termen är en efterhandskonstruktion och att de aktuella filmskaparna under 40- och 50-tal inte relaterade sig till beteckningen film noir på samma sätt som till exempelvis "western" eller"musical".

Trots skiljaktigheter på en teoretisk nivå återkommer kritikerna ständigt till en kärna av 25-30 filmer i diskussionen kring film noir. Många av de sålunda kanoniserade filmerna regisserades av europeiska immigranter, vanligen med tyskt eller österrikiskt ursprung och med bakgrund i en expressionistisk filmtradition. Dit hörde Otto Preminger, Fritz Lang, Billy Wilder och Robert Siodmak. Till dessa kom ett stort antal inhemska regissörer, varav John Huston, Orson Welles, Jules Dassin, Edward Dmytryk, Nicholas Ray och Henry Hathaway alla bidrog med flera framträdande verk. Ofta har dessutom några filmer av Hitchcock räknats till film noir.

Beroende på utgångspunkt betonar studierna inom ämnet i olika grad de drag som anses kännetecknande för film noir. Det kan först och främst handla om en mörk och pessimistisk livssyn och en därmed sammanhängande koncentration på kriminaliteten och vad den avslöjar om människans dolda sidor. Inslag av för sin tid uppseendeväckande brutalitet är vanliga. Ofta har man understrukit sambandet mellan film noir och det stegrade intresset för freudianskt färgad djuppsykologi under 40-talet. Medan de manliga huvudpersonerna gärna karaktäriserats som moraliskt ambivalenta, t.o.m. vacklande i sin maskulina identitet, har kritikerna samtidigt framhävt den flitiga förekomsten av femmes fatales, hotfulla och sexuellt laddade kvinnor. Med undantag för de hårdkokta hjältarna i filmatiseringarna av Hammetts och Chandlers romaner, har filmerna dessutom framförallt intresserat sig för förövare och offer. Vare sig filmen följer brottslingar i deras desperata ansträngning att undkomma, den oskyldigt dömde som söker upprättelse, eller den som obönhörligt går mot sin egen död,

11 Ställningstaganden i denna diskussion formuleras i bl.a. Raymond Borde och Etienne Chaumeton, A Panorama of American Film Noir 1941-53 (1955), trans. Paul Hammond, City Lights Books 2002, s. 1; Paul Schrader, "Notes on Film Noir" (1972), i Film Noir Reader, ed. Alain Silver and James Ursini, Limelight Editions 1996 s. 53; Foster Hirsch, The Dark Side of the Screen: Film Noir (1981), Da Capo Press 2001, s. 71 f; Krutnik In a Lonely Street, s. 24; Naremore, More than Night, s. 9-11.

12 Film Noir: An Encyclopedic Reference to the American Style, ed. Alain Silver and Elizabeth Ward, Overlook Press 1992. 
handlar det om människor i kris. Vad gäller narrativa grepp utmärker sig ett antal av de mest diskuterade filmerna för en specifik berättarteknik, präglad av omfattande återblickar - flashbacks" - och ibland även av en subjektiv berättarröst. Film noir förknippas dessutom med en visuell stil, som accentuerar svart-vit kontrastverkan - "chiaroscuro" - favoriserar nattliga och regniga storstadsexteriörer, och gärna utnyttjar extrema kameravinklar. ${ }^{13}$

Sunesons Fäll ing a tårar visar sin närhet till denna filmtradition på flera olika sätt. Romanen kan naturligtvis redan genom sin komposition väcka associationer till den rörlighet mellan olika miljöer och karaktärer som är karaktäristisk för filmmediet, något som också en av de dåtida recensenterna uppmärksammade. ${ }^{14}$ Övergången mellan scenerna, ofta utan förklarande eller introducerande berättarröst, kan likaledes uppfattas som filmtypisk. Film tematiseras också i romanen på ett aningen ironiskt sätt, då Suneson låter två av sina personer se filmatiseringen av hans egen I dimma dold, som bör ha haft premiär ungefär samtidigt som Fäll inga tårar kom ut, i november 1953.

Viktigare är emellertid att romantexten genomgående har en starkt visuell karaktär av ett slag som ofta kan jämföras med just film noir. Återkommande uppmärksammar texten olika ljuskällor - innebelysning, gatlampor - som då gärna kontrasteras mot skuggor och mörker och det hot som däri döljer sig: 'Ljuset från fönstret räckte inte så långt. Över taket och en del av väggen. Så blev det stora mörka skuggor. Och mörkast var det bort mot dörren till hallen. Där var skuggorna som långa, mörka fingrar. Som något hemskt och otäckt som inte borde vara" (s. 56). Eller i en annan passage: "Ljuset från skrivbordslampan var ganska knappt. En kort, vit ljuspelare ner från en mörkgrön skärm. Ljus över vita papper med anteckningar, över hennes rynkiga händer mot bordets trägula fibrer, över en flik av hennes vita dräkt, över korkmattan bort mot dörren. En rundad ellips över korkmattan bort mot dörren. I övrigt skuggor" (s. 180).

Stockholm blir också i Sunesons text just den regnvåta, mörka storstad som intimt förknippats med film noir, som här i ett avsnitt där det dystra stadslandskapet samstämmer med känsloläget hos den flyende Stefan Marck:

Han började gå in mot staden. Långsamt och lite haltande. Ryggen värkte fortfarande, han visste inte varför och han ville inte försöka tänka efter varför. Han bara gick i sin ensamhet. Genom regnet och mörkret och halvljuset under lyktorna. Över tusentals slitna gatstenar, mattblänkande i fukten och regnet, korsande järnvägsspårens rostbruna skenor, förbi tunga lagerbyggnader och förbi otaliga, kantiga lyftkranar, genom regnet och diset mot något som kanske var ett mål i ensamheten. (s. 49)

Upplevelsen av staden blir vid några tillfällen av den hotande, klaustrofobiska karaktär som direkt erinrar om expressionistisk filmteknik: "Benickebrinkens backe var mycket brant och de slipade stenarna hala och förrädiska. Fasaderna klämdes hop upp mot Svartmangatan

13 Se Borde och Chaumeton, A Panorama; Schrader "Notes on Film Noir"; Hirsch The Dark Side of the Screen; Krutnik In a Lonely Street, Naremore More than Night; Women in Film Noir, new edition, ed. Ann Kaplan, British Film Institute 2000; Nicholas Christopher, Somewhere in the Night: Film Noir and the American City, The Free Press 1997; Andrew Dickos, Street with no Name: A History of the Classic American Film Noir, The University Press of Kentucky, 2002.

14 Hans Ullberg, ”Pytt i panna”, Expressen 5.11.1953. 
och lyktorna var sparsamma och oklara i regndiset. Han hajade till lite inför en skylt. Hjärtat högg till och det kröp av olust längs ryggen" (s. 59). I romanens slutfas motsvaras den stigande tröttheten och förtvivlan hos Marck av skräckbilder från ett City, där jämförelsen med urtidsdjur får understryka stadens omänsklighet. Texten får här karaktär av korthuggen scenanvisning:

En liten vilsegången månskära som smög kring mellan sotsvarta skorstenar och tvära takprång. Tunga husmassor uppe till vänster. Hus med sneda gavlar och trötta tegelstenar som hotade att släppa i fogarna. Hus som stöttades av stålblanka strävor, med kraftiga timmerstockar, med långa längder av plank. En oändlig sluttning av grus och sand. Själva Brunkebergsåsen blottad och bar. Och så en vid, rundbukig, svällande vågig slätt med en väg och mjuka stenkullar och sand. Och en kantig grävskopa som en svart dinosaur i det diffusa skenet från gatlyktorna nere vid Hötorget. Konserthusets massiv snett bakom ryggen. Tryckande och tungt. (s. 176)

Grävmaskinen återkommer i den utpräglat visuella scen där en medlem av narkotikaligan bränns till döds: "Och så reste sig som en fantastisk jätteödla armen från grävskopan under bron upp mot honom. Den reste sig upp mot den koboltblå himlen, en hämnarens hand höjd till slag..." (s. $215 \mathrm{f})$.

Forskare har påpekat att också inramningar av den fiktiva verkligheten i en skönlitterär text, t.ex. via ett fönster, kan ge associationer till filmen. ${ }^{15}$ Suneson utnyttjar sådana inslag vid ett tiotal tillfällen i romanen: "Omedvetet hade han dragit sig närmare fönstret. En färja från Djurgården gled in mot kajen vid Räntmästartrappan. Människorna myllrade ut som från en myrstack. Försvann upp i spårvagnar, till bussar och hem till lugnet och tryggheten efter nöjeskvarterens hets” (s. 55). Intressantare ändå är hur romanen använder en annan visuell ram, spegeln, och samtidigt ger den en stark symbolisk laddning.

Spegeln uppträder vid mer än ett dussin tillfällen i romanen, däribland i dess mest avgörande situationer. När Vivianne bryter relationen med Marck, ser han hennes uttryck i spegelglaset och upptäcker att "hon hatade honom" (s. 9). Stående bakom henne fortsätter han att stirra in i spegeln, ser hur hennes vackra ansikte blir "kallt och härjat", varefter Vivianne skrattar honom i ansiktet. "Det var som om spegelglaset spruckit framför honom" står det omedelbart innan han utdelar det slag som blir kvinnans död (s. 11). Spegeln hjälper här till att avslöja den falska kvinnans dubbelhet, en funktion flera uttolkare funnit också i den dåtida filmkonsten. ${ }^{16}$

Men spegeln får även representera den självprövning Marck tvingas in i efter dråpet. Den berättarröst som ibland gör sig gällande i romanen har på ett ställe poängterat om Stefan Marck att "han hade aldrig i sitt liv tagit ett ansvar" (s. 129). I den skiss över hans levnadshistoria som finns i romanens början berättas att han som elvaåring slog sönder spegeln i familjens lägenhet (s. 12), en episod som symboliskt tycks understryka den brist på självrannsakan som kommer att utmärka hans vuxenliv. Redan på en av de första sidorna ser sig Marck, då fortfarande namnlös men betecknad som "mördaren", i spegeln: "Ljuset från rek-

15 Ohlsson, Läst genom kameralinsen, s. 57 f.

16 Janey Place, "Women in Film Noir", i Women in Film Noir; Maaret Koskinen, Spel och speglingar. En studie i Ingmar Bergmans filmiska estetik, Norstedts 1993. 
tangeln över dörren var mycket svagt. I spegeln framför sig såg han konturen av sitt ansikte. En mörk oval med två svarta hålor, där ögonen höll till. Det är det jag har talat till, tänkte han. Den enda jag har kunnat tala till. Den enda som har fătt dela min hemlighet" (s. 8). Frågorna om skuld och ansvar blir i texten nära anknutna till spegelbilden: "Förr eller senare måste man ta sitt ansvar, stå för vad man gjort, visa att man var en riktig människa och inte ett kräk. Inte ett fegt och undfallande kräk, som inte vågade tala ut” (s. 8). I finalen, då Marck slutligen har blivit funnen av Kjell Myrman, råkar han av misstag ånyo slå sönder en spegel och utropar: "Jag har alltid krossat speglar. Vad betyder egentligen en spegel?" (s. 218, orig: s kursiv.) innan han kastar sig ut genom fönstret och dör. Antydan till ett svar kommer med romanens absolut sista replik, då Myrmans närmaste man O. P. Nilsson konstaterar: "Vi ser oss inte så ofta i spegeln" (s. 224).

Romanens anknytning till film noir finns också i dess narrativa grepp och dess motiv. Flera centrala noir-filmer utgår liksom Fäll inga tårar från en situation strax före upplösningen och presenterar sedan förhistorien via återblickar, som gärna är präglade av huvudpersonens subjektiva perspektiv. Hit hör bl.a. Wilders Double Indemnity (Kvinna utan samvete), 1944, och Garnetts The Postman Always Rings Twice (Vilse), 1946 - i båda fallen berättas händelseförloppet av den manlige mördaren. Varianter på denna teknik uppträder i ytterligare ett antal filmer, bl.a. Siodmaks The Killers (Hämnarna), 1946 och Tourneurs Out of the Past (Skuggor ur det förflutna), 1947. På ett generellt plan kan sägas att narrationen på så vis får understryka det förflutnas makt över individen, omöjligheten att frigöra sig från de vägval som en gång gjorts.

På motsvarande sätt går personuppsättningen i Sunesons roman att känna igen i film noir. Stefan Marck ter sig som en variant på de manliga huvudpersoner som i en lång rad filmer blir offer för den sexuellt attraktiva kvinnans förförelsekonster. Vivianne representerar vad Janey Place i artikel om kvinnorna i film noir kallar "the spider woman", medan Carina lika uppenbart står för hennes motsats, "the nurturing woman", som erbjuder kärlek och förståelse. ${ }^{17}$ Typiskt nog dör Marck med hennes namn på sina läppar. Den film som är särskilt aktuell för en jämförelse är Fritz Langs Scarlet Street (Kvinna i rött), 1945, där en försynt företagskassör, Christopher Cross, mördar den kvinna han förälskat sig. Liksom Vivianne i Fäll inga tårar har hon då hånskrattande avslöjat att hon enbart utnyttjat honom. Som planläggare i bakgrunden finns också hos Lang en hänsynslös man som kvinnan är alltigenom lojal mot. Slutfasen av filmen beskriver hur Cross i likhet med Marck plågas av inre kval och samtidigt blir alltmera socialt deklasserad under sina vandringar i storstaden. ${ }^{18}$

Frank Krutnik hävdar i In a Lonely Street: Film Noir, Genre, Masculinity att den flitiga förekomsten av femmes fatales inom film noir i själva verket är att uppfatta som ett uttryck för problem inom och mellan män, snarare än som renodlad kvinnofientlighet. Krutnik ser masochistiska tendenser hos flera av de manliga hjältar som inte kan övervinna sin fatala

17 Place, "Women in Film Noir".

18 Bilden av en mardrömsartad urban miljö är inte särskilt tydlig i Scarlet Street, men däremot i bl.a. Jules Dassins Night and the City (Natten och staden), 1950. 
förälskelse och menar i anslutning till Freud att denna idealisering av kvinnan vittnar om att den manliga identiteten är undergrävd. ${ }^{19}$

Också i Sunesons roman finner vi ett intresse för just instabil manlighet. Vivianne som styckets fatala kvinna får ganska lite uppmärksamhet och den ondskefulla list hon utövat gentemot Stefan Marck reduceras i någon mån då det visar sig att hon är narkoman. Marcks handlande framstår inte heller som orsakat enbart av kvinnans försåt, utan redan i skissen över hans tidigare levnadshistoria betonas att han flera år dessförinnan var på väg in i ett "högst egenhändigt tillverkat helvete" (s. 13). "Han blev allt hårdare, allt mer jäktad, allt mer cynisk", bedömer den berättarröst som här liksom på andra ställen talar med en auktoritet som Marck däremot helt kommer att förlora under slutskedet av sitt liv. Berättelsen förmedlar på så sätt en annan moral än Langs Scarlet Street, där den blygsamme och äktenskapligt hunsade Cross snarare får illustrera naivitetens möte med en ond värld. Marck är samtidigt inte heller ensam i romanen om att illustrera en manlighet på väg mot katastrofen. "Jag håller på att bli alkoholist", får Kjell Myrman erkänna för sig själv vid flera tillfällen, medan han fortsätter att bälga vittvin (s. 105, 110). Den sönderstressade Myrman fungerar som redan nämnts i flera avseenden som Marcks spegelbild, knuten tätt till honom via den narrativa tekniken. På detta stadium av Sunesons utveckling av polisromanen omfattas sålunda även hjälten-detektiven av krissymptomen.

\section{Polisromanen}

I kriminalromanens värld förblev polisen länge i skuggan av geniala privatdetektiver. Från Conan Doyle och genom pusseldeckarens glansperiod under mellankrigstiden tilldelades polismakten så gott som genomgående den otacksamma rollen att genom sin enfald och fantasilöshet kontrastera mot Sherlock Holmes och alla hans efterföljare. ${ }^{20}$ Annorlunda förhåller det sig med Georges Simenon, som 1931 inleder den långa serie av romaner där Pariskommissarien Maigret blir huvudperson. Fallen löses här inte via det logiskt-matematiska resonerande som krävs inom pusseldeckaren, utan genom hårt och metodiskt arbete och därutöver genom Maigrets intuition, erfarenhet och grundliga kunskap om parisiska miljöer och människor. Genreteoretikerna har haft en tendens att behandla Simenon som ett särfall, omöjlig att kategorisera, men väsentliga drag i hans romaner återkommer även hos de författ-

\footnotetext{
19 Krutnik, In a Lonely Street, s. 82, 112. I Krutniks tolkning blir också den komplicerade narrationen med återkommande "flashbacks" i t.ex. Siodmaks The Killers och Tourneurs Out of the Past, två filmer om manliga förlorare, tecken på den manliga auktoritetens sönderfall. Berättelsen framförs inte med den kraftfullhet som ett enhetligt perspektiv kan ge. Den splittrade narrationen kan naturligtvis också sägas förstärka andra motiv typiska för film noir, inte minst bilden av storstaden som ibland får karaktär av hotfull labyrint. Om storstaden som labyrint i film noir, se Christopher, Somewhere in the night, s. $1 \mathrm{ff}$.

20 Undantag fanns redan på 1800-talet med bl.a. Wilkie Collins och Emile Gaboriau, och under 20och 30-talet med den då populäre F. Wills Crofts. Vad gäller den senare är det värt att lägga märke till att hans romaner skiljer sig från samtidens pusseldeckare endast i så måtto att det här är högt begåvade poliser istället för privatspanare som löser likaledes mycket komplicerade fall.
} 
are som från andra världskrigets slut formar polisromanen till en egen subgenre inom kriminallitteraturen. ${ }^{21}$

Till de som vanligtvis framhålls som banbrytare i denna utveckling hör på engelsk botten John Creasey, som under pseudonymen J. J. Marric skrev en rad romaner om kommissarien George Gideon. Bland de amerikanska författarna nämns gärna Lawrence Treat och Hillary Waugh, medan Ed McBains Cop Hater (Avslöjad) från 1956, den första romanen i en populär och mönsterbildande serie om 87:e polisdistriktet, kan ses som det definitiva genombrottet för polisromanen. Hos kritikerna återkommer några faktorer som får förklara den förändring som skedde inom kriminalfiktionen. Utvecklingen ses av Stephen Knight i Form and Ideology in Crime Fiction som en anpassning till publikens krav på en realism, som avvisade "the naive illusions of past crime fiction" och istället hade präglats av mediernas intensiva rapportering från världskrigets verklighet. Knight betonar också hur tilltron till polisen vuxit med krigsårens erfarenheter: "Total war involved both general experience and widespread acceptance of bureaucratic organisation, and communicated a notion that security could come from organised, technically skilled collective effort."22 På liknande sätt argumenterar Leroy Lad Panek i The American Police Novel, där han dels hävdar att polisromanen var ett sätt att ge kriminallitteraturen den samtidskänsla som pusseldeckaren saknade, dels ser en direkt motsvarighet mellan världskrigets stridande förband och de disciplinerade, effektiva och manligt dominerade kollektiv som polisromanen kom att ställa i centrum. ${ }^{23}$

Man kan invända mot Knights och Paneks bakgrundsteckning att polisromanen ända fram till sextiotalet fortfarande levde i skuggan av kriminallitteraturens äldre varianter. Världskriget åstadkom alltså inget omedelbart genombrott för den nya subgenren. Däremot gav krigstidens och det kalla krigets strävan till nationell samling en stark ideologisk karaktär åt många av de texter om polisen som producerades under denna period. De återkommande bilderna av polisens resurser och effektivitet och av plikttrogna och självuppoffrande polismäns otacksamma arbete i en storstadsdjungel tillfredsställde alltså inte bara krav på realism, utan också politiska behov.

Texterna om polisen fick en relativt lös form, som gav möjlighet till större narrativ variation än i den strama pusseldeckaren. Fokuseringen på polisens arbete kunde fortfarande kombineras med en gåta av traditionellt slag, men vanligare var att läsaren fick följa en utredning som inte begränsades till en från början given krets av misstänkta. Vidare kunde författaren antingen, som Simenon, koncentrera sig på en huvudperson, eller, som McBain, växla mellan olika medlemmar av poliskollektivet. I en del fall frångick romanerna den konventionella inriktningen på ett enda brottsfall för att istället beskriva hur en polismans vardag upptas av en mångfald ärenden. Såväl Creasey som McBain ger exempel.

21 John C. Cawelti, Adventure, Mystery and Romance. Formula Stories as Art and Popular Culture; Chicago University Press 1976, s. 126 ff; Julian Symons, Lilla mordboken. Från detektivhistoria till kriminalroman - en historik, övers. Sune Karlsson, Berghs 1979, s. 175. Leroy Lad Panek, The American Police Novel. A History, MacFarland \& Company, 2003, s. 41, 50, betonar Simenons betydelse även för amerikanska författare.

22 Stephen Knight, Form and Ideology in Crime Fiction, MacMillan 1980, s. 169; Symons, Lilla mordboken, s. $176 f$.

23 Panek, The American Police Novel, s. 41, 77. 
Efterkrigstidens berättelser om polisen tillkom i en interaktion olika medier emellan. Både Knight och Panek understryker den stora betydelse flera radioserier och, från 1952, även TV-serien Dragnet hade för utvecklingen av polisromanen, dock utan att närmare diskutera hur genren präglades av detta samspel. Jag vill framförallt betona hur polisromanen - och dess motsvarigheter inom film och TV - istället för pusseldeckarens snävt intellektuella inriktning erbjöd ett intresse för mänskliga relationer och på så sätt kunde tillmötesgå en bredare publik. Polisiära arbetslag i olika typer av texter kan ofta uppfattas som representationer av hur människor överhuvudtaget fungerar inom moderna professioner med höga krav på yrkesskicklighet och samarbete. Texterna kan idealisera polisgrupper genom att framhäva deras ömsesidiga lojalitet och föredömliga ledarskap, men de kan också ge inblickar i hur könsfördomar, personlig rivalitet och slitsamma arbetsförhållanden präglar tillvaron för en yrkesgrupp. ${ }^{24}$ Polisfiktionen har dessutom, liksom andra typer av populärkulturella texter kring t.ex. sjukhus, skolor eller advokatkontor, sökt skildra hur den enskilde reagerar inför trycket från yrkets och privatlivets olika krav. Redan Simenon ägnade åtskillig uppmärksamhet åt Maigrets äktenskapliga förhållanden. Den harmoni publiken där mötte har i senare tid ofta förbytts i gestaltningar av polismän och poliskvinnor som däremot omöjligt kan finna balans i sina liv.

Märkligt nog tonar Panek tonar ner den roll de samtida filmerna spelade för polistexterna efter världskrigets slut: "Films about cops (...) were infrequent and largely undistinguished", skriver han. ${ }^{25}$ Omdömet ter sig inte välgrundat. Med början 1945 och Henry Hathaways The House on 92:nd Street (Huset vid 92:a gatan) produceras i Hollywood och av framstående regissörer en rad filmer med poliser i centrum. En kategori har beskrivits som "semidokumentär" i sin strävan att till synes autentiskt skildra det moderna, kollektivt präglade polisarbetet i den amerikanska storstaden. Till denna grupp hör bl.a. Dassins The Naked City (Storstad), 1948, Werkers och Manns He Walked by Night (Nattmänniskan), 1949, och Kazans Panic in the Streets (Panik på öppen gata), 1950. Kritiker har ibland uppfattat dessa filmer som glorifierande i sin bild av polisen. Deras ideologiska prägel förstärks också gärna via inslag av reportagefilm och speakerröster som i likhet med krigstidens propagandafilm vill övertyga om myndigheternas vaksamhet. ${ }^{26}$ En helt annan tendens framträder i de filmer som istället fokuserar på enskilda, psykologiskt komplicerade polismän och deras problematiska förhållande till det ständiga umgänget med våld, bl.a. Premingers Where the Sidewalk Ends (Nattens vargar), 1950, Wylers Detective Story (Polisstation 21), 1951, och Rays On Dangerous Ground (Farlig mark), 1952. Samtliga de manliga huvudpersonerna i dessa tre filmer är obalanserade, hårt pressade av sin arbetssituation och mer eller mindre

24 Senare tids TV-serier ger goda exempel. Den danska Mordkommissionen (Landsholdet)och den amerikanska The District ter sig båda idealiserande i sin bild av polisen, medan den engelska I mördarens spår (Prime Suspect) snarare fokuserar på olika konflikter inom yrkeskåren.

25 Panek, The American Police Novel, s. 77.

26 Krutnik, In a Lonely Street, s. $203 \mathrm{ff}$. 
brutala - som karaktärer typiska för film noir. Kontrasten är stark mot den betryggande bild av polisen som annars dominerar inom såväl filmen som litteraturen. ${ }^{27}$

Vic Sunesons författarskap utvecklas i spänningen mellan dessa ibland djupt olikartade texter om polisen. Med Kjell Myrman och I dimma dold visar sig en nervigare polishjälte än tidigare i den svenska kriminallitteraturen, delvis modellerad efter Dana Andrews rollkaraktär i filmen Laura, och med samma svårigheter som denne att bevara fattningen inför den vackra kvinnliga huvudpersonen. Myrman, som inledningsvis ensam får träda fram ur en i övrigt helt anonym poliskår, bär sedan i Fäll inga tårar på uppenbara likheter med de neurotiska och hårt slitna polismän som gestaltats inom film noir. "Varför skulle han alltid engagera sig så personligt $\mathrm{i}$ allt han höll på med?", frågar han sig själv vid ett tillfälle (s. 94). Hans alkoholproblem framstår via sammanhanget som ett resultat av arbetets krav och kulminerar med den följande romanen, Döden kastar långa skuggor. Myrman söker där rekreation på en fjällsemester, men är ånyo oförsiktig med spriten och vaknar en morgon med ett kvinnolik i sitt sovrum.

Det blir O. P. Nilsson, som med en blandning av bister faderlighet, vänskaplig lojalitet och omutlig professionalism stöttar Myrman i dennes ansträngningar att rentvå sig. Redan i $\ddot{A} r$ jag mördaren? hade Myrman tilldelats en parhäst i den äldre polisman, som då fortfarande kallas P. O. Nilsson, men som från och med Fäll inga tårar får initialerna omkastade och därefter en vidgad roll i Sunesons romaner. Även i Och häcken växte delar de två på arenan, men därefter avpoletteras Myrman och O. P. Nilsson blir ensam kvar, nu i ledningen för en mindre grupp. Suneson har med Så spelar döden funnit en modell som utnyttjar de skiftande personligheterna i ett kollektiv och som han fortsättningsvis skall utnyttja i de flesta av sina följande 22 böcker. Liksom Simenon håller Suneson fast vid en tydlig huvudrollsinnehavare och vid koncentrationen på ett enda fall, men han ger samtidigt betydligt större utrymme för Nilssons underlydande.

Påfallande är att Sunesons författarskap skiftar karaktär i flera avseenden. Den mörka stämning som präglade både Stockholmsmiljön och de introverta figurerna i Fäll inga tårar saknas helt i Så spelar döden. Inte heller står att finna någon uppenbar inspiration från filmtypiska grepp. Suneson föredrar visserligen ofta ett berättande som begränsar sig till karaktärernas iakttagbara yttre, men denna teknik kan lika gärna spåras tillbaka till Hemingways s.k. "kameraöga" som till filmen. Framförallt dominerar i romanen en rapp och ironiskt underfundig dialog, som dels får understryka samspelet poliserna emellan, dels poängterar komiken i konfrontationerna med vittnen och misstänkta. Liksom i Fäll inga tårar ställs olika karaktärer omväxlande i fokus och även nu följer romanen delvis en misstänkt på flykt, men tonvikten ligger i högre grad på det polisiära arbetslagets insatser. I centrum står O. P. Nilsson som en erfaren och slitstark ledare för ett team, vars varma relationer till varandra gärna tydliggörs.

27 En negativ bild av poliskåren som helhet ges i några samtida engelska romaner. Julian Symons inleder med The 31 st of February (Den 31 februari), 1950, en serie av, som han själv benämnde dem, "crime novels" som bröt med pusseldeckarens konventioner och där samhällskritiken bl.a. sköt in sig på de rättsvårdande myndigheternas inkompetens. I John Binghams My name is Michael Sibley (Mitt namn är...),1952, framträder polisen som hänsynslös i sin behandling av misstänkta. 
De nya inslagen i Så spelar döden förenas med starkt konventionella. Brottsfallet hör hemma i den medelklass och borgerlighet, gärna med konstnärliga ambitioner, som pusseldeckaren föredragit även i sina svenska varianter hos Trenter och Lang. Antalet misstänkta är från första ögonblicket begränsat till offrets släktingar, som misstänks ha handlat utifrån ekonomiska motiv. Utredningen blir i vanlig ordning en granskning av alibin och snäva tidsmarginaler. Vägen till upplösningen innehåller en del överraskande vändningar. Suneson skulle även fortsättningsvis begagna denna kompromiss mellan nytt och gammalt, mellan pusseldeckarens traditioner och polisromanens annorlunda karaktär.

Sunesons utveckling kan uppfattas som en triumf för de starka tendenser som återkommit inom kriminalromanens historia. Den långa serien, baserad på en konventionell litterär teknik och med stående huvudpersoner, har dominerat genren alltsedan Conan Doyle. Experiment av den art som ges prov på i Är jag mördaren? eller Fäll inga tårar förblir undantag. Publiken erbjuds och föredrar ofta det redan välbekanta, där variation skapas via gåtorna. Med en produktionstakt av i genomsnitt en bok om året stimuleras också författaren att utnyttja en uppsättning fasta ingredienser. Polisromanen, som för Suneson får en stabil form med Så spelar döden, ger honom en egen nisch på den svenska deckarmarknaden. Den till synes oföränderligt stabile O. P. Nilsson överensstämmer också bättre med samtidens normer än den problematiske Myrman, som snarast kan sägas förebåda de många nutida, krisdrabbade polishjältarna med Henning Mankells Wallander som exempel.

Möjligtvis kan man också se förändringarna i den amerikanska filmen som en bidragande faktor till att Suneson söker nya mönster. Den inspiration som film noir tidigare gett avmattas vid mitten av 50-talet. Paul Schrader betonar teknikens betydelse, hur technicolor och det nya cinemascopeformatet hårdlanseras i konkurrensen med TV, men också hur maccarthyismen medför ett krympande utrymme för allt som kan misstänkas vara samhällskritiskt. Generellt efterträds pessimismen i den noir-typiska filmkonsten av vad Schrader kallar "ludicrous affirmations of the American way of life". ${ }^{28}$

Omsvängningen i Sunesons produktion får konsekvenser för texternas ideologi. En text som Fäll inga tårar saknar sådana "betryggande" eller "ideologiskt bekräftande" inslag som teoretikerna på området gärna uppfattat som karaktäristiska för genren. ${ }^{29}$ Visserligen drabbas gärningsmännen Stefan Marck och Alf Aramo båda av en död som möjligen kan tolkas som utslag av en högre rättvisa. Men poliserna har då romanen slutar ännu inte lyckats genomskåda sammanhangen och den konfliktfyllde och vinberoende Myrman är definitivt inte ägnad att stärka förtroendet för ordningsmakten.

Bilden av det moderna samhället är också mörkare än hos någon av Sunesons svenska rivaler. De karaktärer som lyfts fram ur den dystra storstadsbakgrunden är med få undantag egoistiska, penninglystna och sedeslösa. Marcks väg mot förfallet innebär dessutom att han tangerar en undre värld, som annars är praktisk taget okänd i samtida svenska deckare. Fäll inga tårar fokuserar framförallt på narkotikahanteringen, men även sutenörer, gatuprostituerade, pedofiler och solochvårare av den mest hänsynslösa sorten tillhör det sociala registret i Su-

28 Schrader, "Notes on Film Noir", s. 61.

29 För en diskussion kring dessa frågor se Ulf Carlsson, "Stieg Trenter-genren och samtiden", i HumaNetten, vårnumret 2005, www.vxu.se/hum/publ/humanetten. 
nesons 50-talsromaner. I Fäll inga tårar ter sig själva stadslandskapet laddat med oroande symbolik då det talas om det hål som skapats mitt i centrum i och med tunnelbanebygget - "som om en jättelik grävskopa grabbat tag i bebyggelsen och krafsat åt sig en knippa hus" (s. 108).

Texten signalerar ett orsakssammanhang bakom det onda. I presentationen av Marcks livshistoria talas det om "ett amerikaniserat, privat och högst egenhändigt tillverkat helvete" (s. 13, min kurs.). Den stressade livsföring som Marck representerar och som explicit kännetecknas av cynism och hårdhet beskrivs som ett typiskt amerikanskt fenomen. Berättelsen avslöjar hur såväl den falska Vivianne som narkotikahajen Aramo har sitt ursprung i USA. I en räcka scener får läsaren följa hur knarket distribueras via flyget från New York. En direktör vars förbindliga yta uppenbart döljer en slughet beskrivs som "[m]ycket amerikansk" (s. 95). I en rapsodisk bild av Stockholm förmedlad via Myrmans medvetande framstår staden närmast som invaderad av USA-inslag - dollargrin, artister, nattklubbar. Vid ett annat tillfälle sammanfattar kommissarien fallet och säger om Vivianne: "Hon var för resten inte den enda i den här historien med rötter i Amerika. Hela eländet kom därifrån, så mycket visste man" (s. 147, 131).

Medan Myrman kan ses som ett offer för kristendenserna i tiden, ter sig O. P. Nilsson desto mer stabil. Inför mordoffret Viviannes städhjälp får han redogöra för sin syn på polisarbetet: "...det är ett jobb. Ett jobb som måste göras. Vi är också en sorts städtanter, om ni förlåter ordet. Vi rensar upp, när dumma och elaka människor har skräpat ner, ställt till och burit sig åt” (s. 153). Det något naiva ordvalet kan uppfattas som ett utslag av den faderliga stränghet som utmärker Nilssons hållning till omvärlden, men Suneson understryker samtidigt de hotfullare sidorna av hans väsen. I Så spelar döden betecknas han både som "dödligt farlig" och som diabolisk och hans huggormsgrin och kyliga blick fungerar som två ofta återkommande attribut. ${ }^{30}$ Överhuvudtaget underhåller Suneson fascinationen inför huvudpersonen inte i första hand genom att ge tillträde till hans tankevärld, utan snarare genom att registrera hans livliga minspel och gestik.

Inte minst blir O. P. Nilsson representant för en traditionell svensk livsstil, en man som har sitt trygga fäste i den villa i Äppelviken, bakom vars vita grind hustrun väntar med pölsa och grisfötter. ${ }^{31}$ Redan i Fäll ing a tårar blir ett kort avsnitt kring Nilssons stillsamma hemmakväll en enstaka, idyllisk ljusglimt i storstadsskildringen (s. 133 f). Som respekterad chef och som en man som förkroppsligat folkhemsambitionen genom att stiga från små omständigheter till en ansvarsfull post, framstår han som en korsning mellan Per-Albin Hansson och Simenons Maigret. Den senare har av Dennis Porter träffsäkert beskrivits som en nationellt präglad hjältefigur, kännetecknad såväl av typiskt småborgerliga franska seder som av självständighet och en kritisk hållning till överheten. ${ }^{32} \mathrm{O}$. P. Nilsson ter sig som en direkt motsvarighet på svensk botten. Suneson återkommer i flera romaner på 60-talet till polismannens sociala

30 Vic Suneson, Så spelar döden, Gebers 1956, s. 89, 270.

31 Suneson, Så spelar döden, s. 164, 178.

32 Dennis Porter, The Pursuit of Crime. Art and Ideology in Detective Fiction, Yale University Press 1981, s. $202 \mathrm{ff}$. 
bakgrund. Karaktäristiskt nog framställs dennes uppväxt i Stockholms Sibirien som utmärkt av knapphet men hederlighet. ${ }^{33}$

Till skillnad från Maigret hamnar däremot sällan Nilssons nutida privatliv i fokus. Hustrun Gudrun får t.ex. aldrig träda fram i kroppslig gestalt i romanerna, utan förblir den troget väntande makan i bakgrunden. O. P. Nilsson är först och främst den gode ledaren för ett polislag, som i sin tur ger en idealiserad bild av hur manlig vänskap och effektivitet förenas på en demokratiskt präglad, svensk arbetsplats. I Så spelar döden återkommer scener med ett hårt arbetande roddarlag under befäl av en coach, för kommissarien uppenbart en träffsäker metafor för hans egen verksamhet.

Sunesons romaner kan till sist ses i en bredare kontext. Historikern Kim Salomon urskiljer en mera kritisk bild av "framtidslandet" USA som ett alternativ till den beundran för det amerikanska som dominerade i 50-talets Sverige. Salomon påvisar hur även "skuggsidorna i det amerikanska samhället", däribland kommersialism, ytlighet och kriminalitet, skildrades i dåtidens svenska veckopress. I olika artiklar kontrasterades dessa amerikanska avarter mot en förment svensk gemenskap, trygghet och trivsel. ${ }^{34}$ På liknande sätt lät Vic Suneson de nedärvda nationella värdena bestå vakthållningen i det moderna Sverige. Den amerikanisering som hotar i Fäll inga tårar motvägs av lanseringen av O.P. Nilsson och hans team som garanter för folkhemmets dygder.

Källor

Analyserad litteratur

Mord kring Maud, Gebers 1948.

I dimma dold, Gebers 1951.

Är jag mördaren?, Gebers 1953.

Fäll inga tårar, Gebers 1953.

Döden kastar långa skuggor, Gebers 1954.

Och häcken växte, Gebers 1955.

Så spelar döden, Gebers 1956.

Fredagen den 14:e, Gebers 1960.

Vem av de sju, Gebers 1967.

\section{Filmer}

Black Angel (Objuden gäst), 1946. Regi: Roy William Neill.

Detective Story (Polisstation 21), 1951. Regi: William Wyler.

Double Indemnity (Kvinna utan samvete), 1944. Regi: Billy Wilder.

He Walked by Night (Nattmänniskan), 1949. Regi: Alfred Werker och Anthony Mann.

The House on 92:nd Street (Huset vid 92: a gatan), 1945. Regi: Henry Hathaway.

The Killers (Hämnarna), 1946. Regi: Robert Siodmak.

Laura (Laura), 1944. Regi: Otto Preminger.

The Naked City (Storstad), 1948. Regi: Jules Dassin.

33 Vic Suneson, Fredagen den 14:e, Gebers 1960; Vem av de sju, Gebers 1967.

34 Kim Salomon, En femtiotalsberättelse. Populärkulturens kalla krig i folkhemssverige, Atlantis 2007, s. 143 f, 154. 
The Night and the City (Natten och staden), 1950. Regi: Jules Dassin.

On Dangerous Ground (Farlig mark), 1952. Regi: Nicholas Ray.

Out of the Past (Skuggor ur det förflutna), 1947. Regi: Jacques Tourneur.

The Postman Always Rings Twice (Vilse), 1946. Regi: Tay Garnett.

Scarlet Street (Kvinna i rött), 1945. Regi: Fritz Lang.

Somewhere in the Night (Jagad i natten), 1946. Regi: Joseph Mankiewicz.

Where the Sidewalk Ends (Nattens vargar), 1950. Regi: Otto Preminger.

\section{Citerad och refererad litteratur}

Bang, "Tår på tand", Dagens Nyheter 10.11.1953.

Bingham, John, Mitt namn är...(My Name is Michael Sibley, 1952), Berghs 1957.

Borde, Raymond och Chaumeton, Etienne, A Panorama of American Film Noir 1941-53

(1955), trans. Paul Hammond, City Lights Books 2002.

Carlsson, Ulf, "Stieg Trenter - genren och samtiden", i HumaNetten, vårnumret 2005, www.vxu.se/hum/publ/humanetten.

Cawelti, John C., Adventure, Mystery and Romance. Formula Stories as Art and Popular Culture; Chicago University Press 1976.

Christopher, Nicholas, Somewhere in the Night: Film Noir and the American City, The Free Press 1997.

Creasey, John (J. J. Marric), Gideons dag (Gideon's Day, 1955), Wennerbergs 1959.

Dickos, Andrew, Street with no Name: A History of the Classic American Film Noir, The University Press of Kentucky 2002.

Duncan, Paul, Noir Fiction, Dark Highways, Pocketessentials 2000.

Film Noir: An Encyclopedic Reference to the American Style, ed. Alain Silver and Elizabeth Ward, Overlook Press 1992.

Hirsch, Foster, The Dark Side of the Screen: Film Noir (1981), Da Capo Press 2001.

Horsley, Lee, The Noir Thriller, Palgrave 2001.

Knight, Stephen, Form and Ideology in Crime Fiction, MacMillan 1980.

Koskinen, Maaret, Spel och speglingar. En studie i Ingmar Bergmans filmiska estetik, Norstedts 1993.

Krutnik, Frank, In a Lonely Street: Film Noir, Genre, Masculinity, Routledge 1994.

McBain, Ed, Avslöjad (Cop Hater, 1956), Wennerbergs 1957.

Naremore, James, More than Nigh: Film Noir in its Contexts, University of California Press 1998.

Ohlsson, Anders, Läst genom kameralinsen. Studier i filmiserad svensk roman, Nya Doxa 1998.

Olsen, Steinar, "Vic Suneson i toppform", Aftontidningen 2.11.1953.

Panek, Leroy Lad, The American Police Novel. A History, MacFarland \& Company, 2003.

Pillerthrillaren, 'Thriller-piller", StockholmsTidningen 5.111953.

Place, Janey, "Women in Film Noir", $i$ Women in Film Noir, new edition, ed. Ann Kaplan, British Film Institute 2000.

Porter; Dennis, The Pursuit of Crime. Art and Ideology in Detective Fiction, Yale University Press 1981.

Salomon, Kim, En femtiotalsberättelse. Populärkulturens kalla krig i folkhemssverige, Atlantis 2007. 
Schrader, Paul, "Notes on Film Noir" (1972), i Film Noir Reader, ed. Alain Silver and James Ursini, Limelight Editions 1996.

Simenon, Georges, Mannen som såg tågen gå förbi (L'Homme qui regardait passer les trains, 1938), Bonniers 1950.

Symons, Julian, Den 31 februari (The 31"st of February, 1950), Bokhuset 1981.

Symons, Julian, Lilla mordboken. Från detektivhistoria till kriminalroman - en historik, övers. Sune Karlsson, Berghs 1979.

Ullberg, Hans, "Pytt i panna", Expressen 5.11.1953.

Waugh, Hilary, Vid försvinnandet iklädd (Last Seen Wearing-, 1952), Gebers 1964.

Werner, Gösta, De grymma skuggorna. En studie i Stig Dagermans författarskap och dess relationer till filmen som medium, Norstedts 1986.

Women in Film Noir, new edition, ed. Ann Kaplan, British Film Institute 2000.

Woolrich, Cornell, (George Hopley), Natten har tusen ögon (The Night has a Thousand Eyes, 1945), Askild \& Kärnekull 1973. 